\title{
Yttrium Y 90 Anti-CD45 Monoclonal Antibody BC8
}

National Cancer Institute

\section{Source}

National Cancer Institute. Yttrium Y 90 Anti-CD45 Monoclonal Antibody BC8. NCI

Thesaurus. Code C95698.

A radioimmunoconjug ate containing the murine IgG1 anti-CD45 monoclonal antibody (MoAb) BC8 labeled with yttrium 90 (Y90), with potential immunotherapeutic activity. Yttrium Y 90 anti-CD45 monoclonal antibody BC8 binds to CD45 antigen, a receptor protein-tyrosine phosphatase expressed on the surface of both normal and malignant hematopoietic cells. After binding and internalization by CD45-expressing tumor cells, this agent may deliver a cytotoxic dose of beta radiation. 